\title{
Jesus - prophetic emissary of God
}

\author{
Estelle Dannhauser \& Andries G van Aarde* \\ Department of New Testament Studies \\ University of Pretoria
}

\begin{abstract}
The present study examines three models of research, all reaching the same conclusion, namely that Jesus was a prophet. The aim is to determine what their point of origin in research was, to determine on what basis they have grounded their research and conclusions, and to draw a comparison between both the routes they have chosen and their destinations at the end of these routes. This study likewise detects similarities between Jesus and the prophets of the Old Testament and considers the possibility that the cadre of classical prophecy may be one that describes the ministry of Jesus, if not fully, then at least to a large extent. Lastly the phenomenon of prophecy is examined to test their conclusions and to try to determine whether any research gaps that may have been left, need to be filled.
\end{abstract}

\section{INTRODUCTION}

Scholars and lay audiences alike have, in their various and diverse encounters with Jesus, from as far back in time as the lifetime of Jesus and up to the present, reacted from instinct and exclaimed: "A prophet!"

Epiphanius (see University Microforms International 1976:499-500) wrote in his Panarion at the end of the fourth century CE: "Jesus ... was called an archangel, not messiah, and was recognized as the true prophet." He writes further on the beliefs held sacred by the Ebionites (a "syncretisticgnostic group") which "was characterized by the combination of Jewish monotheism with Gentile elements": "Jesus was venerated as a naturally procreated man upon whom the Holy Spirit descended at baptism, which gave him the status of prophet" (see University Microforms International 1976:42).

From an entirely different direction in scholarship comes a similar recognition; Johannes Weiss ([1892] 1971) wrote that Jesus was "a misguided

\footnotetext{
"This article is based on the PhD dissertation "Jesus - Prophetic emissary of God". This dissertation, with Prof Dr A G van Aarde as supervisor, was submitted and accepted as part of the requirements of the PhD degree (2006), Department of New Testament Studies, Faculty of Theology, University of Pretoria.
} 
eschatological prophet who lived in expectation of the imminent, apocalyptic end of the world."

The present article examines three different routes of scholarship and their eventual destinations in the age-old, well-trodden quest for the historical Jesus. This is a brief travel guide to the extensive work done by the three scholars, N T Wright (1992, 1996, 2003), J D G Dunn (2003a, 2003b) and R A Horsley (1985, 1987, in Horsley [\& Draper] 1999), with much appreciation for their work and the way it broadened my own horizons. Since they all travel their various routes with the explicit purpose of reaching a clear view of the authentic Jesus, we shall compare the views they offer upon reaching their destination. We shall also examine the possibility of clarifying their various views if we were to colour the background with more detail made possible by different strands of scholarship.

There appears to exist a research gap in their work, for although they all discover Jesus to have been a prophet, they fail to realize in their work the full implications of the prophetic office. The research goal in the present work is to examine the possibility of clarifying their various views if we were to colour the background with more detail made possible by different strands of scholarship. Current prophetic research by Old Testament Scholars can illuminate more fully the comparison between the office of Jesus and that of the prophets of old. This would, however, comprise a voluminous study. The aim of this article is to supply a link between the findings of these scholars and Old Testament research on the subject by means of a reminder of the basic introductory features of prophecy and how it may enrich our understanding of Jesus.

Before embarking on our own journey, however, it is important to examine maps of routes traveled in the past in this quest. Our aim will be to determine the strengths and possible shortcomings of these routes, and subsequently to charter a map of our own.

Wright $(1996: 20,21)$ coined the phrases "Wredestrasse" and "Schweitzerstrasse", thereby indicating the different routes taken by these scholars on which they were guided or not by the Markan and Matthean map, with the following they had gained along their separate ways. To accommodate current scholarship he widens his analogy to an "Autobahn" carrying heavy traffic in lots of different lanes. In order to choose which of the two routes to follow, scholars need to ask themselves: "Do we know rather little about Jesus, with the gospels offering us a largely misleading portrait (Wrede)? Or was Jesus an apocalyptic Jewish prophet, with the gospels reflecting, within their own contexts, a good deal about his proclamation of the 
kingdom" (Schweitzer 1996:21)? This analogy of Wright's will serve as a marker along our way.

Samuel Reimarus (1694-1768) ignited the fuse that would blow apart the complacency with which the scholarly world had accepted the gospel material as sources for Jesus-research up until then. Talbert (1870:64) writes that Reimarus had found enough motivation in the course of his research to acknowledge a sharp dichotomy between what Jesus himself had said and taught on the one hand, and what the apostles, being themselves teachers and holding forth their own views additionally to those of Jesus, had written on the other hand. One of the strengths of the teaching of Reimarus is that it reminds the scholar that Jesus himself wrote nothing and that these gospels are virtually our only sources for any kind of cognition of the words and actions of Jesus.

The work of David Friedrich Strauss (1808-1874) was no less controversial, indeed Baird (1992:246) describes the work of Strauss as "the most revolutionary religious document written since Luther's Ninety-Five thesis." In his book entitled "The life of Jesus critically examined", Strauss (1972) compounds his conviction that the gospels can in no way be seriously considered as sources, being filled with tales of the supernatural and irreconcilable differences as they clearly are. He dubbed the gospels "myth", conglomerations of mythological fabrications with Jesus as subject, compiled by his followers into narratives which may or may not be true. These theories caused a second seismologic ripple throughout the scholarly world and ricocheted back to Strauss' own life and faith, causing him to part ways with faith and Jesus, neither of which had any further meaning for him. He expected "honest, upright men" to do the same and distance themselves from being Christians.

In 1892, Weiss (1971), like Strauss, had despaired of finding a historical Jesus of any relevance whatsoever behind the gospel portrayals. The "misguided eschatological prophet" of his acquaintance expected an imminent, apocalyptic end to the world as we know it and had no relevance to

Albert Schweitzer (2000:478) finds resonance with the work of Weiss, believing him to be the only scholar who displays sufficient courage to follow through the evidence regarding the eschatology of Jesus, the apocalyptic preacher whose worldview sits so uncomfortably on the ear and mind that he "... will be to our time a stranger and an enigma."

However, Schweitzer believed that by placing Jesus within the context of apocalyptic Judaism, the scholar is at liberty to assume much greater continuity between Jesus, the early church and the gospels, of course always bearing in mind the different historical settings in each case (see N T Wright 1996:21 in this regard). In the introduction to Schweitzer's "the mystery of the 
Kingdom of God", Walter Lowrie (1950:33) writes: "Schweitzer rehabilitates the credit of S Mark's Gospel simply by showing that no important parts of it need be discarded on the ground that they are inconsistent with the sketch which he draws of the history of Jesus."

Lowrie (in Schweitzer 1950:34) further comments on the "positive and comforting element" in the work of Schweitzer which, for Lowrie, "greatly simplifies and clarifies the synoptic problem in attributing much less gospel material to the hand of the editor." Schweitzer (2000:xxxv) urges critical study of the gospel to be open to the "late-Jewish eschatological material found in the utterances of Jesus according to the two oldest Gospels. It must agree to recognize at least some of it."

Quite the antithesis is William Wrede whose influential work on Mark, entitled "The messianic secret", argues that the gospel in question is undeniably the result of dogmatic and theological rather than historical concerns. Wrede (1971:131) states his case that Mark is nothing more than a document of faith, affording the reader the merest crumbs of historicity, namely that Jesus was a Galilean teacher whose words and deeds resonated with his audience and that Jesus was finally executed. Schweitzer (2000:xxxviii) protests:

\footnotetext{
Those who take the opposite view have to cut large sections out of the two oldest Gospels as later additions, leaving only a thoroughly mutilated text of which nothing can be made. Those, on the other hand, who allow Jesus to think along eschatological lines can accept the text as it stands. The trustworthiness of Matthew and Mark forces itself upon them all the time, being confirmed in a way hitherto inconceivable by the new light thrown by eschatology on their problems and meaning.
}

However, in responsible research the scholar stands to gain from heeding the warning of Wrede, namely to continue searching behind the Gospel of Mark for sources, in spite of the difficulties such a search may present, for the material within this Gospel may already be an interpretation of the facts theology instead of history.

\section{N T WRIGHT}

It is important at the starting line to ascertain which sources were utilized by Wright. Only if the conclusion - that Jesus was a prophet - is based on reputable sources and a sound methodology in the reading and interpretation 
thereof, can this conclusion be accepted as valid. This will therefore be the first link-up with Wright in the portrait he paints of Jesus.

Wright (in Borg \& Wright 1999:20) makes it clear that he cannot embark on his journey in search of a true picture of Jesus without enlisting the aid of both history and faith to illuminate his way. At the starting line he addresses the issue of sources and what to make of them. The solution which offers itself to him most readily is the inclusive one which accumulates and incorporates all possible information in one grand hypothesis. He makes the decision to examine every scrap of evidence as source and uses all available material, just like any good historian would do.

The theory that in New Testament research the problem of the literary relationship between the gospels has to be solved before attempting to navigate from the sources to Jesus, Wright (in Borg \& Wright 1999:20) declares "notoriously complex". Seeking answers to questions of relationships between sources, what sources they might have used, a three-stage development within the source material comprising oral traditions, their coagulation into literary sources and the collection and the subsequent editing of these sources, are all very well, but prove, according to Wright, to be totally unanswerable. In terms of sources then, and in particular as regards the Gospel of Mark, Wright (1996:81) seems to display solidarity with Schweitzer rather than with Wrede, as is implied by the following quotation:

History, abhorring the vacuum left by the dismissal of Mark as pure
fiction, has come up with new fictions which seem harder to attack
only because they are based on nothing at all. The blithe
"reconstruction" not only of Q, not only of its different stages,
betokens a naïve willingness to believe in anything as long as it's
nothing like Mark.

Thus it is clear that Wright is convinced of the insolubility of the question of the literary relationship and inter-dependence between the sources. He is, furthermore, inclined to attach much less importance to the two-source hypothesis than the majority of scholars in the past two hundred years seem to have done. The $\mathrm{Q}$ source fails to convince him because of its tenuous character and speculative nature and therefore he believes this source unworthy of being bestowed with classification as "gospel" and fails to see the point of efforts to reconstruct this (according to him) fictitious document (see Wright 1996:41-43). Three criteria are applied by Wright (in Borg \& Wright $1999: 22,23)$ as to the applicability of the data, namely: 
- Does it make sense as it stands?

- $\quad$ "Does it have an appropriate level of simplicity, or even elegance?" (Wright, in Borg \& Wright 1999:22).

- $\quad$ Does it illuminate any areas of research apart from the one it was created to cover?

He asks these questions within the wider context of the beginnings of Christianity, its why's and wheretofores.

Along the road mapped by his chosen methodology, his first landmark is Judaism. The Judaism of the first century is by nature a religious typification. It denotes the Jewish monotheism subscribed to by people who shared the conviction that their god, the God of Israel, was the only god and moreover, that he had elected them to be his people. A closer examination of its motives and beliefs reveals, according to Wright (in Borg \& Wright 1999:32), a first-century Jewish eschatology ("... the belief that history is going somewhere, that something will happen to put it right" [Wright, in Borg \& Wright 1999:32]). This entailed the conviction that their god would imminently intervene in the course of history to save and exonerate his chosen people and to ring in his kingdom of peace and justice for all. They had endured exile as punishment for their transgressions, but even after their deliverance from exile, continued foreign dominion shackled them to the retribution for their sins. The promises issued by the great prophets of old, which still begged fulfillment, held them afloat. They expressed the buoyancy of their hopes in language reminiscent of the return from exile, for when God appeared to their rescue, it would be like the dawning of the new exodus.

Against this backdrop of eager anticipation, a first-century Jew by the name of Jesus walked the dusty Palestinian roads. His manner and actions were reminiscent of that of a prophet, his words and message rang true in accordance to ancient prophetic tradition. What he said, superponated constructively with the expectation fecund within their own hearts, for he verbalized in his message and actions their expectation of the imminent arrival of the God of Israel to proclaim himself king and to inaugurate his kingdom.

In a world where religion and politics walked hand in hand and piety and uprising intermingled, the hopes cherished for the coming kingdom were both religious and political. In the climactic moment of Israel's existence God's children would gain access to a new spiritual experience, and would live by a rejuvenated moral code.

However, the kingdom announced by Jesus (Mt 4:17, 23; 9:35; Mk 1:14-15; Lk 4:43; 8:1; 9:2; Ac 1:3) differed somewhat from the one expected 
by Israel and the enemy was not Rome but the one behind Rome. With him Jesus was already engaging in battle, the final battle preceding the establishment of God's kingdom on earth. And through the words and deeds of Jesus the kingdom was already manifesting in the world. He was blatantly throwing down the gauntlet in front of the powers that were - Herod, Caiaphas, Rome itself, those with militant delusions of grandeur within Israel's ranks, the perpetrators of injustice, ostracism and oppression in society through acts of prophetic symbolism.

The message of Jesus issued an open invitation to fellowship within this kingdom, a welcome to all and sundry to become the new covenant people. God intends for inhabitants of his kingdom a guilt-free zone where debts would be written off and sins forgiven. In his turn, he would expect his subjects to show the same forgiving spirit, abolishing barriers erected to keep people out, and banishing oppression of fellow-Israelites. Jesus invited sinners to enjoy fellowship with him and to become citizens of the kingdom. He offered them forgiveness for their sins out on the streets, bypassing cultic means of sacrifice and temple in doing so. His hortative to Israel was to join the ranks of the kingdom-people through repentance and belief in the gospel he was bringing, turning the other cheek, giving also the under-garment, walking the extra mile, losing one's life to gain it and relinquishing militant aspirations.

Wright expresses appreciation for the lone voice of Schweitzer proclaiming Jesus, not a revolutionary in accordance with the majority of opinions of his time, but a prophet with an apocalyptic expectation that his god (Wright prefers the use of the lower casing) would bring the world to an imminent end - as a matter of fact during his own ministry. Schweitzer points out that, although this failed to happen, the message of Jesus nonetheless initiated an eschatological movement which would in time come to be known as Christianity. Likewise appreciated by Wright is Schweitzer's insistence that Jesus be seen within his historical context. Schweitzer believed that the eschatological emphasis he discovered in the teaching of Jesus places him firmly within the context of apocalyptic Judaism. This, according to Wright, enabled Schweitzer and enables the scholar to include far more gospel material in their research than Wrede had deemed legitimate (Wright 1996:20).

Schweitzer's ([1906] 1954:328-401) research led him to conclude that Jesus is painted by the gospels, when read within their own context, as an apocalyptic prophet proclaiming the kingdom. Jesus envisioned a kingdom of his god the manifestation of which would end world history. When his vision failed to materialize, he threw himself upon the great wheel of history in an effort to force it to turn. Although he was crushed in the process, he 
succeeded in turning it. So he became the one who took upon himself the "Great Affliction" (Schweitzer, in Wright 1996:19) which was about to befall Israel and the world.

The modus operandi chosen by Wright leads him to the conclusion that Jesus was an apocalyptic prophet who anticipated an imminent end to the world and delivered an urgent "eschatological, and indeed apocalyptic message" (Wright 1996:150) for the people of Israel. When the world fails to come to an end, he becomes a martyr in his disappointment. Through his death as martyr he forces the wheel of God to turn full cycle. Wright's conclusion is markedly similar to that of Schweitzer in this regard.

Although often misunderstood, Jesus had a strong sense of his prophetic vocation, of being emissary for the one he called "Abba", a conviction that, in the task entrusted to him by his Father, he would not want for strength and guidance from God. Jesus was fully aware that his vocation was a dangerous one (e.g., Mt 20:17-19; Mk 10:32-34; Lk 18:31-34; Mt 21:3344; Mk 12:1-11; Lk 20:9-18). Indeed, in the welcome he issues, he warns that following him - being the light of the world - meant political danger, even death. He gave them the assurance, however, that through trial and tribulation God would sustain them and deliver them into the dawning of the new day.

For those who rejected his message and failed to heed his warning to repent, however, the consequences would be dire and the retribution swift for they would, like a portion of the nation, Jerusalem and the Temple, be targeted in the wrath of God. As part of his kingdom-program Jesus launched an attack on the treasured and revered symbols of his time, such as the Torah, Temple, Jerusalem and the Sabbath. As a result of this, his death was inevitable.

\section{R A HORSLEY}

Horsley finds it worthwhile to attempt delving behind the Gospel of Mark for sources informing the scholar about the Jesus of history. He therefore finds himself inclined to the "Wredestrasse" rather than the "Schweitzerbahn".

Horsley (1999:1) sets out to examine Q as source in order to see whether it would yield any unadulterated information on Jesus. He investigates the possibility of studying traditions of Jesus devoid of theological concepts and assumptions about, as well as elaborations on Jesus' words. Absent are titles such as "Christ", as well as any references to crucifixion or resurrection, among others. The reason why Horsley (in Horsley \& Draper 1999:1) selected this source in spite of the obvious challenges a study of $Q$ would entail, are the following: 
- $\quad$ Sidestepping the miracle accounts in the gospels, $\mathrm{Q}$ allows the reader to access the teachings of the "great prophet" (Horsley 1999:1).

- $\quad$ Horsley believes that it is possible to detect theologizing present even in as early a gospel as that of Mark. Amidst the tarnished reputation and diminished value of the gospel material as a result of the evangelistic interpretation, Horsley (1999:1) finds the Q source - a collection of seemingly reliable sayings - a welcome relief.

- It introduces the scholar to a very different profile of Jesus in comparison to the ones found in either Mark or Luke.

- “... [l]t is intriguing to get behind the written Gospels to an earlier, more "original' source through which Jesus might be understood" (Horsley, in Horsley \& Draper 1999:1).

One of the main arteries of Horsley's argumentation is that Q should be approached, not as an written text, but a tradition such as "... the predominantly oral communication environment of antiquity,... performed orally before groups of people" (Horsley, in Horsley \& Draper 1999:3). In the opinion of some, texts such as $\mathrm{Q}$ are the copies or transcripts of an oral performance before a group of people.

In spite of the seemingly tenuous nature of this source, Horsley believes a stable core to have been maintained within $\mathrm{Q}$ through repeated oral performances. Enshrined within oral transmission and solidified through continuous enactment, Horsley believes that the material pertaining to Jesus in this source was safely preserved, the backdrop of his Jewish cultural origin intact. Horsley (in Horsley \& Draper 1999:11) studies not the great Jerusalem cultural tradition, but the little tradition cultivated "orally and almost certainly with certain regional variation among the villagers who comprised the vast majority of the people" (Horsley, in Horsley \& Draper 1999:11). He sets himself the goal of being able to pinpoint in each discourse what the performers meant to communicate "in relation to Jesus, for whom they speak, and to the communities, to whom they speak" (Horsley, in Horsley \& Draper 1999:12).

Horsley believes that a responsible interpretation of $Q$ as a source necessitates the application of a realistic historical sociology to the material in question as well as a warning against depoliticising Jesus and his mission. Like the prophets of old, Jesus felt a passionate concern for the social issues of the day, the oppression of the poor by the rich not being the least of these. 
An examination of the contents of $Q$ leads Horsley to the conclusion that a resemblance exists between the Jesus of $Q$ and Elijah and Elisha, the two political prophets of old. Horsley reminds his reader that in the offices of Elijah and Elisha no insurmountable borders existed between the political and religious spheres of life, so that they could, and indeed often did, amalgamate.

Horsley likewise finds a resemblance between the role of Jesus and that of a prophet such as Moses. Similarities are the close communion with God, leading God's people to deliverance and establishing Israel as the people of God's covenant. He finds Q 6:20-49 strongly reminiscent of covenant renewal and discovers an urgency in the mission of Jesus to renew the covenant. When commissioning envoys to ensure covenantal renewal, Jesus is ensuring the continuation of his program of covenantal renewal. Horsley once again detects similarities with great prophetic figures of the Old Testament, this time with Elijah, who employed similar measures to ensure the continued renewal of the covenant. The prophetic Jesus found in $Q$ announced the kingdom of God, but not in the sense of the annihilation of the world. The kingdom envisioned by the $\mathrm{Q}$ Jesus is a political metaphor, a symbolic realignment of society according to the principles of the covenant. Horsley believes that the scholar searching for a clearer understanding of Jesus and Q, should invest his time and efforts in the books of the Hebrew prophets, rather than in sapiential literature or the Gospel of Thomas.

\section{J D G DUNN}

Dunn, in his approach, ventures somewhere between the Wredestrasse and the Schweitzerbahn in search of the purist's view of Jesus. He examines an extensive selection of sources in an effort to shed light on how Jesus was remembered and what impact he had made on his followers. In these sources he hopes to trace patterns in the earliest stages of the traditioning process.

His endeavors lead him, in this respect, to the same conclusion as Horsley, namely that a greater degree of stability and continuity was reached within the Jesus tradition than had previously been believed. This he ascribes to the pattern and technique of oral tradition. In the oral traditioning process there are elements prone to flexibility - the peripheral detail - as well as elements likely to remain stable - the key elements which constitute the core. An understanding of these elements would be essential to any kind of comprehension of how the Jesus tradition has been transmitted.

Dunn writes that there is no other Jesus to be found than the remembered Jesus. He is convinced that there was a concern among disciples of Jesus to preserve the narratives and teaching, words and deeds of Jesus, for this would form for them their central identifying component. The 
Jesus tradition of the Gospels confirms that remembering Jesus had been a matter of concern within earliest Christianity and that the process of imprinting upon the collective memory his words and actions, indeed his life, occurred by continuous use and regular repetition in the oral mode of the original and immediate impact made by Jesus. Contrary to popular belief the initial formative impact had not been Easter faith, nor was the impulse to formulate tradition only experienced in the post-Easter period. Rather the original impression of what Jesus had said and done in the pre-Easter call to faith, and which had drawn his first disciples into discipleship, had been translated into the words of the eyewitnesses. "In that key sense, the Jesus tradition is Jesus remembered" (Dunn 2003:882).

Dunn's examination of the traditioning process leads him to a greater appreciation of the synoptic gospels as sources to be reckoned with. In Dunn's opinion they do not cloud, but indeed shed light upon the view of Jesus and can contribute to a meeting between the scholar and the Jesus of memory. He believes furthermore, that we are presented in the Gospels with the living tradition of Christian celebration which retrojects the reader back to the heart of the very first memories of Jesus with surprising immediacy.

Like Horsley, he follows a trail initially laid by oral traditioning and finds a Jesus unwilling to lay claim to any title for himself. He rejects at least one title bestowed on him by others and seems to view himself as a mere instrument in the proclamation of that which stood central in his message: the Kingdom of God. "[H]is role was a role in relation to that, rather than an assertion of his own status as such. Evidently, it was his proclamation of the kingdom which was important; the identity of the proclaimer was a secondary matter" (Dunn 2003:761, 762).

Dunn (2003:662) believes, however, that Jesus was seen to fit the role of prophet. There are indications that he drew on Isaiah 61:1-3 as agenda for his mission. Dunn (2003:662) writes that Jesus' application of "the programmatic prophecy of Isaiah 61:1-3 to inform his own mission" may indicate that they both instructed and inspired him. Dunn is also convinced that he deliberately shaped his mission to coincide with that of the classic prophetic priorities. Like Horsley, Dunn believes that he did so particularly in championing the cause of the poor and sinner in the face of the unconcern of the establishment and the impertinence of their priorities to the matters at hand. He stood up, in true prophetic tradition, for the oppressed who were totally insignificant on the scale of priorities in the eyes of an establishment infamous for their unconcern and lack of empathy with those at the opposite end of fortune. 
Jesus is clearly under the impression of a prophetic commissioning from God. Dunn lists the texts in which Jesus said either that he was sent, or that he came, the implication seemingly being that he was sent by God. Dunn believes it to be possible that these texts suggest an awareness of prophetic commissioning on the part of Jesus. The texts to which he refers are: Mark 2:17, Luke 19:10; Matthew 10:34, Luke 12:49; Mark 10:45, Matthew 20:28; Mark 9:37, Luke 9:48; Matthew 10:40, Matthew 15:24, John 13:20 and Matthew 18:20.

Jesus is vividly remembered within tradition as a person displaying prophetic insight and foresight and his actions clearly reminded his followers of, not the sign prophets, but the great prophets. Scholarship (referred to in Dunn 2003:664) has drawn attention to some of these actions such as his choice of twelve followers, his eating with toll-collectors and sinners, his healings and exorcisms, his entry into Jerusalem, the symbolic Temple-action and the last supper.

There are, moreover, indications that Jesus understood his own mission to transcend that of prophet. Dunn (2003:666) sums up: "[T]here need be little doubt that Jesus was regarded as a prophet by many, that he saw himself in the tradition of the prophets, and probably also that he claimed a(n eschatological) significance for his mission (and thus himself) which transcends the older prophetic categories." The righteous would suffer, indeed anyone placing God's will before all else could anticipate suffering or death.

The questions of why Jesus went to Jerusalem and whether he anticipated his own death remain. Dunn (2003:805) deduces from tradition that Jesus expected to share in the fate of the prophets, their rejection and even their martyrdom in Jerusalem. He concludes that Jesus in all likelihood had seen himself as standing in the tradition of the prophets of Israel and maybe even at the climax thereof. The fate of Israel's prophets and their suffering had become proverbial and Jesus, cloaked in the mantle of prophetic emissary of God, must have been fully aware that prophetic suffering and martyrdom in all probability awaited him. He anticipated the rejection of "his message in Jerusalem, to suffer as a man in the hands of men, to drink the cup of suffering and be fully caught up in the final tribulation" (Dunn 2003:805). Jesus was fully aware that the righteous could expect to suffer and even die for putting God's will before everything else, just as he had probably been aware of the fate that John the Baptist had suffered at the hands of Antipas. All of these realisations almost certainly add up to an affirmative answer to the question of whether he had anticipated his own death. John the Baptist had already lost his life, therefore the mounting hostility against Jesus himself and his mission could hardly have come as a surprise. 
There is, however, a strong indication that Jesus saw the climax to his mission as the climax to God's eschatological purpose:

Jesus (and his disciples) would suffer the final tribulation through which God's kingly purpose would achieve its goal; the kingdom would come. His death would introduce that final climactic period, to be followed shortly ("after three days"?) by the general resurrection, the implementation of the new covenant, and the coming of the kingdom.

(Dunn 2003:824)

But Jesus' reference to Isaiah 61:1-3 may imply a ranking higher than merely that of another prophet. It may indeed imply the (eschatological) prophet. Similarly, when Jesus uses the phrase "I was sent" as well as "I came" it suggests a surpassing of normal prophetic commissioning, just as his usage of "I say to you" transcends the normal prophetic formula of "thus says the Lord". Referring to Matthew 11:6/Luke 7:23, Dunn (2003:665) writes:

This chimes in with the sense of eschatological newness which comes through in several of Jesus' sayings: something greater was happening than the repetition of prophetic hope; something greater than the prophet Jonah, whom Jesus may have ... offered as a sign .... Which in turn strengthens the implication ... that Jesus saw himself, at least as proclaimer of the kingdom, to be part of the eschatological newness which he proclaimed and its offensiveness.

Whereas typical prophets would use the formula: "Thus says the Lord ...", Jesus would use "I say to you ...". Other prophets would use "I was sent ...", Jesus would use "I came ...". His formula of "Amen, I say to you ..." transcends all that was typically prophetic and in exorcism his "I command ..." supersedes the usual "I adjure you by ..." in its unquestionable authority.

Dunn (2003:703) writes that "[t]radition enshrines the possibility" that Jesus explicitly claimed to be the salaam of God, his eschatological emissary and representative. He suggests (Dunn 2003:762) that we can begin to speak more firmly of Jesus as the man who was remembered as one who above all took on the role of eschatological spokesman for God. It takes no further leap in faith to deduce, without strain, something of Jesus' own self-understanding regarding that role - a conviction of being God's eschatological agent at the climax of God's vision for Israel, a sense of intimate sonship before God and 
of the dependence of his disciples on him, and his supposedly strong hope for final acknowledgment as the man who was playing the decisive role in bringing the kingdom to fulfilment and consummation.

Dunn (2003:889) concludes: "Prophet was a category which Jesus seems to have fitted well, and found congenial to characterize much of his mission which is clearly remembered as fully alive to the traditional fate of the prophet to be rejected ...." Although Dunn acknowledges his roles as healer and exorcist - many experienced miraculous healings and happenings in his company - and that he was often hailed as a teacher - he launched scathing attacks on the contemporary system of religious and social values through his parables and aphorisms - it is interesting to note that he sees these offices of Jesus as disjunct from his role as prophet.

The Jesus of memory without a doubt shouldered massive social responsibility - he aimed to bring the good news to the poor and call sinners in a reaffirmation of Israel's constitutional priorities. He set out to encourage and establish a society in which all boundaries between its members are demolished and lives on in memory as one who frequently pronounced that many age-old prophetic hopes are on the point of being realised.

In the three models examined, an excursion into the ancient world of Old Testament prophecy would lend added dimensions to the pictures of Jesus either painted or discovered. Although all three discover in Jesus features which clearly point to the prophetic office of Jesus, they leave a research gap in failing to embed their findings in the world of meaning implied by the word "prophecy". A complete examination of the prophetic phenomenon and its similarities and differences with the office of Jesus is much needed, but could comprise volumes. The next section is therefore an attempt to offer an introduction to such a study by examining basic, textbook aspects of the prophetic phenomenon; a rough pencil sketch of features Jesus' Israelite proletariate contemporaries would have found reminiscent of the age-old oral traditions of the great prophets of history. I will not attempt a perusal into the extensive current scholarship on prophecy, but instead try to connect the initial intuitive reaction to the work and words of Jesus to the basic memories of the prophets of old, who lived on in the minds and hopes of the people of Israel.

\section{PROPHECY}

Prophets were people upon whom the divine had laid claim and were "... entirely devoted, soul and body, to the divinity. They are inspired personalities who have the power to receive divine revelations" (Lindblom 1973:6). 
H L Ellison (1977:14) states that a prophet stands to God as Aaron stood to Moses. He refers to Deuteronomy 13:1, 2 and 18:21, 22 to argue the point that, while foretelling would most certainly come to pass in the mission of the true prophet, this does not necessarily establish his credentials. Compressed into a nutshell, the following are the essential ingredients of the prophetic office:

- $\quad$ At a certain time juncture circumstances may be more favourable to prophetic intervention than normal. It is usually when some eventuality hovers in the skies of international history and politics directly above the people of the covenant that prophets appear to interpret the coming threat to Israel. Prophecy also intervenes in times of gross social and economic injustice. Times in which Israel turns her back on her God to dabble in idolatry and heathen religions similarly are conducive to prophetic action. And when Israel attempts to form political allegiances and plays the political field to the point where God's protection and council seems obsolete, prophets step in to bring God's people to their senses and their God once more.

- $\quad$ There exists an intimate relationship between God, his prophet, and his living word - they are interdependent, inseparable. God's words have absolute authority; they are a driving force in the history of Israel. In the words of Von Rad (1972:73): “... God's thoughts and designs began their historical fulfilment at the point at which they became words on the lips of the prophet."

- "Word" was not to Israel a static concept or mere utterance of thought or emotion. It is considered to be a dynamic force possessing creative power not only in Israel, but also in ancient eastern cultures where the principle of the dunamism of the word in cultic life for spells, exorcisms, blessings and curses is applied. In ancient Babylon and Egypt the word was seen as possessing physical and cosmic capabilities and in the time of Jesus, certain spiritual words were believed to give eternal life. The phrase: "The word of Yahweh came to ..." (which occurs so repeatedly in a book such as Jeremiah that it eventually sounds like a chant or chorus) illustrates this point clearly.

- When God lays claim to the life of a prophet, the prophet has no option but to surrender his words, his whole life and even to some extent the 


\section{Jesus - prophetic emissary of God}

lives of his family into God's service. God would instruct them to engage in various symbolic actions, all of which serve to underline and/or emphasise and/or supplement the words spoken by God's emissary in a way that was sure to shock his audience into hearing and understanding. The symbolic actions were as a rule accompanied by a verbal message, but could also stand alone as self-explanatory.

- Unlike mystics, prophets did not seek contact with the deity but God gave them visions which overcame them. Lindblom (1973:181) says that the great prophets never sought revelatory experiences through ecstatic exercises. The prophetic schools of teaching had as their objective the knowledge of Yahweh (da'at Yahweh) and the preservation of prophetic revelations. In prophecy the prerequisite was that Yahweh sends his word wherever and whenever he wants. The passive state of the prophet and the dynamic action of the divine possession are clearly illustrated by passages such as Ezekiel 40:1: “... the hand of the Lord was upon me and He took me there," and Ezekiel 37:1: "The hand of the Lord was upon me, and he brought me out by the Spirit of the Lord and set me in the middle of a valley." This differs rather radically from the frenzied ecstasies, chanting and self- or substance-induced trances we read of in mystical practices. Divine response is, in the case of the prophets, like the answer to a prayer and there is never any mystical unification with the godhead.

- $\quad$ That suffering is part and parcel of the prophetic package, is plain to see from the lives of the prophets known from the Old Testament, as well as from John the Baptist's life and death. Whether it is the result of the prophet's isolation from his people as he stands before God exclusively, or of the fact that his personal convictions clash head-on with those he has to announce to his people, whether it entails bringing messages of fire, brimstone, destruction and deluge to his own people, or whether he suffers as a result of prosecution, suffering and prophecy are intimately related.

- $\quad$ The prophetic message is a double-edged sword, announcing vindication for some, judgement for others. Prophets speak with divine authority. The calling of a prophet by God endows him with a huge amount of creditability and divine authority. The divine calling is usually reported on in descriptive detail. It portrays the life-changing implications of the experience. 
- $\quad$ Lindblom (1973:179) explains the symbiosis between prophet and Spirit as follows:

... the prophet is filled with the spirit or anointed with the spirit. Two
features in the conception of the spirit must be kept in mind: first,
the spirit does not come from within the human soul; it comes from
outside, surprisingly, wonderfully, impressively -'the spirit fell upon'
the prophet; secondly, the spirit was never thought of as an
independent power ... but always as a power emanating or rather
sent from Yahweh to convey to the prophetic audience the validity
and legitimacy of his office.

- $\quad$ Prophets call to themselves disciples to spread the word of the new kingdom to come and to assist them in their prophetic activities.

- $\quad$ They use the word "I" with great authority, while meaning in actual fact that they become, in the deliverance of the word of God, mere empty vessels, amphitheatres through whom God speaks and enacts his message to his people in a dramatic way.

It is clear from this brief perusal of the prophetic phenomenon that Jesus meets all these requirements and exceeds them. The circumstances in the time in which he started his public ministry cried out for prophetic intervention. Oppression and non-egalitarian practices were the order of the day. Jesus, the word of God and God himself shared a relationship so intimate that Jesus was seen as and was called both by his followers. Care is taken to enlighten the reader of the Gospels as to the extent to which Jesus was endowed with the Spirit of God, for it was an aspect of his life which obviously inspired awe. He spoke with great authority in his prophetic message and the accompanying actions of miracle, healing and exorcism, authority which, like so many aspects of Jesus' prophetic ministry, exceeds that of regular prophecy.

That there was something unique in the life of and driving force behind the artisan from Nazareth cannot be doubted. Scholars from far and wide, powered by different motivations and travelling along a variety of different roads, have identified him as prophet. They are seemingly correct, if instinct, the evidence to hand, and scholarship may be trusted. But questions as to what type of prophet he may have been, what his eschatological agenda had been and what he had hoped to achieve through his mission fail to find satisfactory answers. And detailed though a description of the phenomenon 
prophecy may be, it always falls short in comparison to the short time in which Jesus taught and lived.

The reason for this is that Jesus may be found at the pinnacle of an office which is already, by its very nature, in close and personal proximity of the divine realms. The resemblances he bears to the prophetic ancestors within the people of Israel are too many to negate, yet one is always tempted to apply the superlative in the case of Jesus.

Is it possible that he had been not only a prophet as even the gojim pointed out, but the prophet of prophets? The scholar seeking to address that question will have to make a leap in faith. For it is necessary to take stock for a decisive moment of one's own faith premises before proceeding.

The essence of being a prophet is his relationship with God. It is God who determines his words, actions and program, God who endows him with his word and power and Spirit. Is this merely delusion or self-induced trancestates? Did Jesus delude himself when he prayed to "Abba" in isolation? Or do we indeed believe that God speaks to and through his prophets and to and through Jesus. If we say that Jesus was steered by the rudder of God's will to the point of suffering and death, was he in reality the author of his own suffering as Schweitzer believed, or did he indeed do the will of his God for humanity?

Even this cursory glance at the prophetic phenomenon will suffice to indicate the possibilities that would be opened up by a thorough comparative study between the life and words of Jesus and those of the prophets of old. If the consequences of such a study were to be applied to the works of Wright, Dunn and Horsley, it would emphasise their contribution considerably by filling the gap in their research. The easy assumption that we automatically know all there is to know about prophecy needs to be replaced by a renewed conscious look at the phenomenon of prophecy and what the implications are when research looks at Jesus and discovers in him a prophetic emissary of God.

\section{Works consulted}

Aune, D 1987. The New Testament in its literary environment. Philadelphia, PA: Westminster.

Baird, W 1992. From deism to Tübingen, in History of New Testament research, Vol I. Minneapolis, MN: Fortress.

Becker, J 1972. Johannes der Täufer und Jesus von Nazareth. Neukirchen-Vluyn: Neukirchener Verlag.

Borg, M J [1984] 1998. Conflict, holiness and politics in the teachings of Jesus. New York: Mellen.

Borg, M J \& Wright, N T 1999. The meaning of Jesus: Two visions. San Francisco, CA: HarperCollins. 
Dunn, J D G 2003a. Jesus remembered: Christianity in the making, Vol I. Grand Rapids, MI: Eerdmans.

Dunn, J D G 2003b. Altering the default setting: Re-envisaging the early transmission of the Jesus tradition. NTS 49, 139-175.

Horsley, R A 1985. Like one of the prophets of old: Two types of popular prophecy at the time of Jesus. CBQ 47, 435-463.

Horsley, R A 1987. Jesus and the spiral of violence: Popular Jewish resistance in Roman Palestine. San Francisco, CA: Harper \& Row.

Horsley, R A 1995. Galilee: history, politics, people. Valley Forge, PA: Trinity.

Horsley, R A \& Draper, J A 1999. Whoever hears you hear me: Prophets, performance and tradition in Q. Harrisburg, PA: Trinity.

Horsley, R A \& Hanson, J S 1985. Bandits, prophets and messiahs: Popular movements at the time of Jesus. Minneapolis, MN: Winston.

Koch, G A 1976. A critical investigation of Epiphanius' knowledge of the Ebionites. [Microform] A translation and critical discussion of Panarion 30. Ann Arbor: University Microforms International.

Lindblom, J [1962] 1973. Prophecy in ancient Israel. Oxford: Blackwell.

Lindemann, A 2001. Die Logienquelle Q: Fragen an eine gut begründete Hypothese, in The sayings source $Q$ and the historical Jesus, 3-26. Leuven: Leuven University Press.

Long, B O 1996. W F Albright as prophet-reformer: A theological paradigm inscribed in scholarly practice, in Reid, S B, Prophets and paradigms: Essays in honor of Gene M Tucker, 152-172. Sheffield: Sheffield Academic Press.

Mack, B L 1988. Mark and Christian origins: A myth of innocence. Philadelphia, PA: Fortress.

Malina, B J 1984. Jesus as charismatic leader? BTB 14, 55-62.

Malina, B J 1993. The New Testament world: Insights from cultural anthropology. Louisville, KY: Westminster John Knox.

Malina, B J 2001. The social gospel of Jesus: The kingdom of God in Mediterranean perspective. Minneapolis, MN: Fortress

Moule, C F D 1967. The phenomenon of the New Testament. London: SCM.

Mowinckel, S 2002. The Spirit and the word: Prophecy and tradition in ancient Israel. Minneapolis, MN: Fortress.

Patterson, S J 1998. The God of Jesus: The historical Jesus and the search for meaning. Harrisburg, PA: Trinity Press International.

Patterson, S J 1993. The Gospel of Thomas and Jesus. Sonoma, CA: Polebridge.

Petersen, D L (ed) 1987. Issues in religion and theology 10: Prophecy in Israel. Philadelphia, PA: Fortress.

Pilch, J J 2002. The nose and altered states of consciousness: Tascodrugites and Ezekiel. HTS 58(2), 708-720.

Reed, J L 2000. Archaeology and the Galilean Jesus. Harrisburg, PA: Trinity.

Reinstorf, D H 2002. Metaphorical stories in Luke's narrative world: A challenge to a conventional worldview. DD dissertation, University of Pretoria.

Renan, E [1863] 1864. The life of Jesus. London: Truebner.

Riesenfeld, H 1970. The gospel tradition. Philadelphia, PA: Fortress.

Ritschl, A [1888] 1902. The Christian doctrine of justification and reconciliation. Edinburgh: $T \&$ T Clark.

Robinson, J A T 1976. Redating the New Testament. London: SCM. 
Robinson, J M 1959. A new quest for the historical Jesus. London: SCM.

Schweitzer, A [1901] 1950. The mystery of the Kingdom of God: The secret of Jesus' Messiahship and passion, tr by W Lowrie. London: Adam \& Charles Black.

Schweitzer, A [1906] 2000. The quest of the historical Jesus, tr by W Montgomery, J R Coates, S Cupitt \& J Bowden. London: SCM.

Strauss, D F [1835] 1972. The life of Jesus critically examined, tr by G Elliot, and ed by Hodgson, P. Philadelphia, PA: Fortress.

Talbert, C H (ed) 1970. Reimarus: Fragments, tr by R S Frazer. Philadelphia, PA: Fortress.

Weiss, J 1971. Jesus' proclamation of the Kingdom of God, edited and tr by R H Hiers \& D L Holland. Philadelphia, PA: Fortress.

Wrede, W [1904] 1908. Paul. Boston: Beacon \& Norgate.

Wrede, W [1901] 1971. The Messianic secret. Translation of Das Messiasgeheimnis in den Evangelien: Zugleich ein Beitrag zum Verständnis des Markusevangeliums, tr by J C G Creig. Cambridge: James Clarke. (The Library of Theological Translations.)

Wright, N T 1992. The New Testament and the people of God. London: SPCK.

Wright, N T 1996. Jesus and the victory of God. London: SPCK.

Wright, N T 2003. The resurrection of the Son of God. Minneapolis, MN: Fortress. 